\title{
PEMBUATAN ASAM OKSALAT DARI PELEPAH KELAPA SAWIT (Elaeis guineensis) MELALUI REAKSI OKSIDASI ASAM NITRAT
}

\author{
Yos Pawer Ambarita, Iloan Pandang H M, Seri Maulina \\ Departemen Teknik Kimia, Fakultas Teknik, Universitas Sumatera Utara, \\ Jl. Almamater Kampus USU, Medan 20155, Indonesia \\ Email : pawera_yos@yahoo.com
}

\begin{abstract}
Abstrak
Asam oksalat merupakan asam dikarboksilat dengan rumus molekul $\mathrm{H}_{2} \mathrm{C}_{2} \mathrm{O}_{4}$ yang memiliki berbagai aplikasi dalam industri. Asam oksalat dapat digunakan sebagai zat pemutih serat, reagen dalam analisis kimia, dan digunakan dalam pemurnian mineral dari logam. Penelitian ini bertujuan untuk mengetahui pengaruh temperatur dan waktu reaksi terhadap kuantitas dan kualitas dari asam oksalat yang dihasilkan melalui reaksi oksidasi asam nitrat terhadap serbuk pelepah kelapa sawit. Pada metode ini serbuk pelepah kelapa sawit direaksikan dengan asam nitrat $40 \%$ pada rasio $1: 6(\mathrm{w} / \mathrm{v})$ dengan temperatur $65,70,75,80$, dan $85^{\circ} \mathrm{C}$ serta waktu reaksi 40, 50, 60, 70 dan 80 menit, untuk memperoleh asam oksalat. Penelitian ini dilaksanakan dalam beberapa tahapan yaitu tahap reaksi oksidasi, filtrasi, pengendapan dengan $\mathrm{CaCl}_{2}$, pengasaman dengan $\mathrm{H}_{2} \mathrm{SO}_{4}$ dan pengkristalan. Kualitas dari asam oksalat yang diperoleh dianalisa menggunakan Fourier Transform Infra Red (FTIR) dan Plat Melting Point Apparatus. Kondisi terbaik untuk pembuatan asam oksalat dari serbuk pelepah kelapa sawit melalui reaksi oksidasi asam nitrat yaitu pada waktu reaksi 50 menit, temperatur $80{ }^{\circ} \mathrm{C}$, dengan yield asam oksalat sebesar $23,20 \%$.
\end{abstract}

Kata kunci: asam oksalat, pelepah kelapa sawit, oksidasi asam nitrat, temperatur

\begin{abstract}
Oxalic acid is a dicarboxylic acid with the molecular formula $\mathrm{H}_{2} \mathrm{C}_{2} \mathrm{O}_{4}$ which has a wide range of applications in industry. Oxalic acid can be used as fiber bleaching agents, reagents in chemical analysis, and also used in mineral purification of metals. This study aims to determine the effects of temperature and reaction time to quantity and quality of oxalic acid produced by nitric acid oxidation from palm frond powder. The method used for the manufacture of oxalic acid in this study is oxidation method. In this method palm frond powder will be reacted with nitric acid $40 \%$ in the ratio $1: 6(\mathrm{w} / \mathrm{v})$ at temperature 65, 70, 75, 80, and $85{ }^{\circ} \mathrm{C}$ and reaction time 40, 50, 60, 70 and 80 minutes, thus obtained oxalic acid. The research was conducted in several stages: oxidation reaction stage, filtration, precipitation with $\mathrm{CaCl}_{2}$, acidification with $\mathrm{H}_{2} \mathrm{SO}_{4}$ and efflorescence. Oxalic acid product quality analyzed using Fourier Transform Infra Red (FTIR) and Plate Melting Point Apparatus. The maksimum yield of oxalic acid was about $23.20 \%$ which obtained at $80{ }^{\circ} \mathrm{C}$ and at reaction time 50 minutes.
\end{abstract}

Keywords: oxalic acid, palm frond, nitric acid oxidation, temperature

\section{Pendahuluan}

Asam oksalat disintesa untuk pertama kali pada tahun 1776 oleh Schleele melalui oksidasi gula dengan asam nitrat. Metode oksidasi dengan asam nitrat juga telah dilakukan oleh beberapa peneliti dengan berbagai bahan baku antara lain, sintesis asam oksalat dari batang rami dengan perolehan sebesar $25,4 \%$ [7], dari biomassa tebu diperoleh massa asam oksalat sebesar 4,606 gram [4], dari limbah sabut kelapa diperoleh massa asam oksalat sebesar 13,826 gram [11], dari sekam padi diperoleh yield sebesar $81 \%$ dan dari bahan baku padi diperoleh yield sebesar 79,9\% [10]. Penelitian - penelitian terdahulu tersebut menggunakan limbah yang mengandung selulosa sebagai bahan baku pembuatan asam oksalat. Limbah yang mengandung selulosa di Indonesia saat ini sangat melimpah, antara lain pelepah kelapa sawit.
Pelepah kelapa sawit merupakan limbah yang dihasilkan dari tanaman kelapa sawit mulai dari pra panen hingga proses pemanenan. Limbah pelepah kelapa sawit dihasilkan dari proses pruning kelapa sawit dimana untuk satu pohon kelapa sawit dapat dihasilkan $22-26$ pelepah setiap tahunnya [1], limbah pelepah kelapa sawit hasil pruning biasanya dibuang begitu saja dan dibiarkan membusuk di bawah pohon kelapa sawit. Pemanfaatan limbah pelepah kelapa sawit mulai dikembangkan misalnya sebagai pakan ternak dan pupuk kompos, namun ditinjau dari komposisi kimianya limbah pelepah kelapa sawit mempunyai potensi yang cukup besar untuk diolah lebih lanjut menjadi produk yang bermanfaat dan bernilai ekonomis, salah satunya dengan memanfaatkan limbah pelepah kelapa sawit sebagai bahan baku pembuatan asam oksalat. 
Pelepah kelapa sawit merupakan limbah perkebunan kelapa sawit yang mengandung polisakarida dalam bentuk selulosa, hemiselulosa dan lignin [13]. Kandungan selulosa pada pelepah kelapa sawit yang tinggi yaitu $31,7 \%$ [3] memberi peluang untuk dimanfaatkan sebagai bahan baku pada pembuatan asam oksalat.

\section{Teori}

Pelepah kelapa sawit merupakan salah satu limbah padat dari perkebunan kelapa sawit yang dapat diperoleh sepanjang tahun bersamaan dengan panen tandan buah segar. Total potensi jumlah limbah pelepah kelapa sawit di Indonesia sebanyak 81.887.936 ton/tahun [14]. Elisabeth dan Ginting (2003) melaporkan bahwa nutrisi pelepah kelapa sawit adalah 5,8 \% protein kasar, $1,07 \%$ lemak, 48,6 \% serat kasar, 3,3\% abu dan $29,8 \%$ total digestible nutrient [3]. Dari data tersebut dapat diketahui bahwa komponen penyusun terbesar dari pelepah kelapa sawit adalah serat kasar, serat kasar pelepah kelapa sawit terdiri dari selulosa, hemiselulosa, lignin dan silika. Komposisi kimia pelepah kelapa sawit dapat dilihat pada tabel 1 [8].

Tabel 1. Kandungan Kimia Pelepah Kelapa Sawit [8]

\begin{tabular}{|l|c|}
\hline Komponen Kimia & Kandungan (\%) \\
\hline Selulosa & 35,88 \\
Lignin & 18,9 \\
Hemiselulosa & 26,47 \\
Zat ekstraktif & 9,05 \\
Air & 9,7 \\
\hline
\end{tabular}

Selulosa adalah polimer $\beta$-glukosa dengan ikatan $\beta-1,4$ di antara satuan glukosanya [9]. Menurut Marbun, selulosa mempunyai sifat-sifat sebagai berikut [2] :

1. Dapat terdegradasi oleh hidrolisa, oksidasi, fotokimia maupun secara mekanis sehingga berat molekulnya menurun.

2. Tidak larut dalam air maupun pelarut organik, tetapi sebagian larut dalam larutan alkali.

3. Dalam keadaan kering, selulosa bersifat higroskopis, keras dan rapuh. Bila selulosa cukup banyak mengandung air maka akan bersifat lunak. Jadi fungsi air di sini adalah sebagai pelunak.

4. Selulosa dalam kristal mempunyai kekuatan lebih baik jika dibandingkan dengan bentuk amorfnya

Selulosa dapat disintesis menjadi asam oksalat melalui reaksi oksidasi menggunakan asam nitrat menurut reaksi berikut [4] :

$$
\begin{gathered}
\left(\mathrm{C}_{6} \mathrm{H}_{10} \mathrm{O}_{5}\right)_{\mathrm{x}} \mathrm{H}_{2} \mathrm{O}+(\mathrm{x}-1) \mathrm{H}_{2} \mathrm{O}+6 \mathrm{xHNO}_{3} \rightarrow \\
3 \mathrm{xC}_{2} \mathrm{H}_{2} \mathrm{O}_{4}+6 \mathrm{xNO} \uparrow+6 \mathrm{xH}_{2} \mathrm{O}
\end{gathered}
$$

Asam oksalat adalah senyawa organik dengan rumus $\mathrm{H}_{2} \mathrm{C}_{2} \mathrm{O}_{4}$. Senyawa ini memiliki sifat-sifat sebagai berikut [11]:

1. Larut dalam air panas maupun dingin serta larut dalam alkohol.

2. Keasamannya lebih kuat dari asam metanoat ataupun asam cuka.

3. Garam-garam alkali oksalat semuanya mudah larut dalam air kecuali kalsium oksalat hanya dapat larut dalam asam kuat.

4. Mudah untuk dioksidasi oleh $\mathrm{KMnO}_{4}$ dalam suasana pada temperatur $60-70^{\circ} \mathrm{C}$.

Asam oksalat dan garamnya dapat digunakan sebagai zat pemutih serat, reagen dalam analisis kimia, dalam pembuatan zat warna untuk kain, di pemurnian logam dalam mineral. Asam oksalat juga digunakan dalam bubuk pembersih sebagai agen penghilang karat dan pemoles logam [12].

Isolasi dan pemurnian asam oksalat dari bahan limbah pertanian dan serbuk kayu sangat layak. Pemanfaatan limbah ini sebagai bahan baku asam oksalat akan membantu dalam penurunan senyawa beracun yang dibuang ke lingkungan dan dapat memenuhi jumlah asam oksalat yang diimpor ke suatu negara [6].

\section{Metodologi Penelitian}

Bahan-bahan yang digunakan dalam penelitian ini adalah Pelepah Kelapa sawit, Asam Nitrat $\left(\mathrm{HNO}_{3}\right)$, Etanol $\left(\mathrm{C}_{2} \mathrm{H}_{5} \mathrm{OH}\right) 96 \%$, Aquadest, Kalsium klorida $\left(\mathrm{CaCl}_{2}\right)$ dan Asam Sulfat $\left(\mathrm{H}_{2} \mathrm{SO}_{4}\right)$

Peralatan yang digunakan dalam penelitian ini adalah Beaker glass, Corong, Erlenmeyer, Gelas ukur, Magnetic stirrer, Hot Plate, Neraca analisis, Neraca analisis, Oven, Waterbath, Termometer, Kertas saring dan Labu leher tiga.

Tahap Preparasi Pelepah Kelapa Sawit

Pelepah kelapa sawit dipotong kecil-kecil untuk mempercepat proses pengeringan. Kemudian dikeringkan dalam oven pada suhu 105 ${ }^{\circ} \mathrm{C}$ selama 30 menit. Selanjutnya dimasukkan ke dalam desikator selama 10 menit dan ditimbang. Pengeringan dilakukan hingga berat pelepah kelapa sawit konstan. Pelepah kelapa sawit yang telah kering kemudian dihaluskan dengan ball mill dan diayak menggunakan ayakan 50 mesh.

Tahap Pembuatan Asam Oksalat

Pelepah kelapa sawit direaksikan dengan asam nitrat. Hasil disaring dan dicuci hingga filtratnya menjadi jernih. Filtrat ditambahkan dengan larutan $\mathrm{CaCl}_{2}$ sampai terbentuk endapan kalsium oksalat kemudian disaring. Endapan dilarutkan dalam $\mathrm{H}_{2} \mathrm{SO}_{4}$, kemudian disaring dan dicuci menggunakan air panas. Filtrat diuapkan menggunakan waterbath kemudian didinginkan 
sampai terbentuk endapan asam oksalat yang berupa kristal jarum berwarna putih. Hasil yang diperoleh dimurnikan dengan proses rekristalisasi menggunakan pelarut etanol.

Analisis Bahan Baku dan Produk

Analisis terhadap bahan baku meliputi analisis kadar air dan selulosa. Sedangkan analisis terhadap asam oksalat yang dihasilkan meliputi analisis yield, titik leleh dan FTIR.

\section{Hasil dan Pembahasan}

Pelepah kelapa sawit yang menjadi bahan baku dalam penelitian ini memiliki kandungan kadar air sebesar $81 \%$ dan kadar selulosa sebesar $31 \%$.

Analisis Yield Asam Oksalat

Yield asam oksalat dihitung menggunakan persamaan berikut :

yield $=\frac{\text { massa kristal asam oksalat }}{\text { massa serbuk pelepah kelapa sawit }} \times 100 \%$

Hasil penelitian pembuatan asam oksalat dari pelepah kelapa sawit melalui reaksi oksidasi asam nitrat dengan pengaruh semua peubah (temperatur dan waktu reaksi) disajikan dalam grafik dibawah ini.

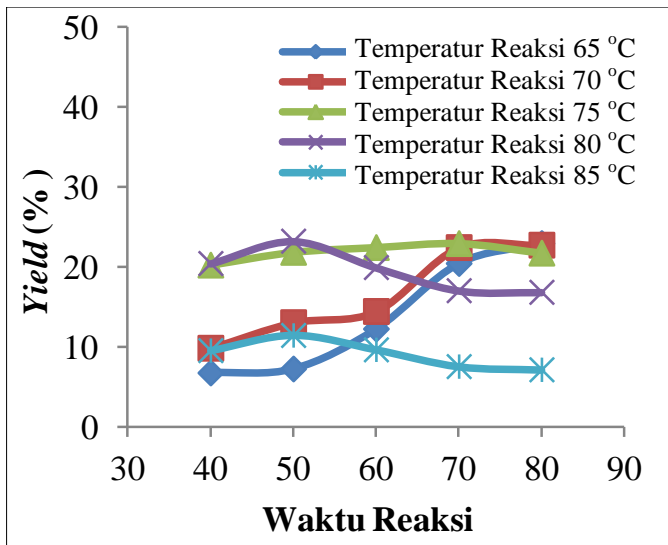

\section{Gambar 1. Grafik Pengaruh Temperatur dan Waktu Reaksi Terhadap Yield Asam Oksalat}

Pada Gambar 1 dapat dilihat bahwa secara umum terjadi peningkatan yield dengan naiknya temperatur dan waktu reaksi. Tetapi akan terjadi penurunan yield dengan terjadinya oksidasi lanjut. Kondisi ini berbeda-beda untuk tiap variabel. Yield asam oksalat akan mencapai titik maksimum pada $80{ }^{\circ} \mathrm{C}$ hanya dengan waktu 40-50 menit. Sementara untuk kondisi temperatur di bawahnya akan mencapai titik maksimum lebih lama dan akan menurun secara perlahan dengan bertambahnya waktu reaksi.

Pada temperatur reaksi yang tinggi yaitu temperatur 80 dan $85^{\circ} \mathrm{C}$, yield maksimum dapat diperoleh dengan waktu reaksi yang lebih singkat yaitu pada waktu 50 menit. Penambahan waktu reaksi pada temperatur ini akan mengakibatkan penurunan yield asam oksalat. Sedangkan untuk temperatur 65,70 dan $75{ }^{\circ} \mathrm{C}$, yield maksimum diperoleh pada waktu reaksi yang lebih lama. Untuk temperatur $65{ }^{\circ} \mathrm{C}$ yield maksimum diperoleh pada waktu 80 menit, sedangkan untuk temperatur 70 dan $75{ }^{\circ} \mathrm{C}$, yield maksimum diperoleh pada 70 menit. Dengan membandingkan reaksi pada waktu yang sama dan temperatur yang berbeda, maka temperatur yang lebih tinggi akan menghasilkan yield yang lebih besar. Hal ini disebabkan karena terjadinya fenomena peningkatan energi kinetik pada molekul-molekul reaktan seiring dengan adanya kenaikan temperatur. Dengan semakin meningkatnya energi kinetik pada molekulmolekul reaktan, maka semakin besar pula kemungkinan terjadinya tumbukan antar molekul reaktan, sehingga mengakibatkan laju reaksi pembentukan produk juga semakin besar.

Perolehan asam oksalat akan menurun apabila temperatur dan waktu reaksi telah melebihi batas optimumnya. Apabila temperatur reaksi terlalu tinggi maka produk asam oksalat akan mengalami dekarboksilasi mengikuti reaksi berikut [5] :

$$
2 \mathrm{H}_{2} \mathrm{C}_{2} \mathrm{O}_{4} \longrightarrow \mathrm{H}_{2} \mathrm{CO}_{2}+2 \mathrm{CO}_{2}+\mathrm{CO}+\mathrm{H}_{2} \mathrm{O}
$$

Hal ini terjadi pada temperatur $85{ }^{\circ} \mathrm{C}$, dimana yield asam oksalat yang diperoleh cenderung kecil pada setiap variasi waktu.

Pada masing-masing temperatur, penambahan waktu reaksi yang melebihi waktu reaksi optimum akan mengakibatkan penurunan yield. Dari grafik dapat dilihat bahwa pada waktu reaksi 40 menit, yield terbesar diperoleh pada temperatur $80{ }^{\circ} \mathrm{C}$. Penambahan waktu reaksi menjadi 50 menit, pada temperatur yang sama dapat meningkatkan yield dari asam oksalat yang diperoleh. Namun apabila waktu reaksi ditambahkan menjadi 60 menit pada temperatur yang sama maka yield akan menurun. Hal ini disebabkan karena untuk waktu reaksi yang semakin lama, yield asam oksalat yang dihasilkan akan semakin tinggi, akan tetapi jika waktu reaksi terlalu lama maka yield akan terus menurun. Penurunan yield tersebut disebabkan oleh adanya reaksi oksidasi lanjut antara produk asam oksalat dengan asam nitrat sisa. Hal ini dapat dihindari dengan mengatur waktu reaksi yang optimum dengan mengurangi resident time sehingga diperoleh asam oksalat sebanyak-banyaknya. Reaksi oksidasi lanjut yang terjadi mengikuti persamaan berikut [11]:

$$
3 \mathrm{H}_{2} \mathrm{C}_{2} \mathrm{O}_{4}+\mathrm{HNO}_{3} \longrightarrow 6 \mathrm{CO}_{2}+4 \mathrm{H}_{2} \mathrm{O}+2 \mathrm{NO}
$$


Berdasarkan uraian di atas, metoda oksidasi akan memberikan yield sebesar 23,20\% dengan waktu reaksi 50 menit, lebih tinggi dibanding metoda peleburan alkali dengan yield sebesar $6,07 \%$ dengan waktu reaksi 60 menit.

Analisis Spektrofotometer Infra Merah

Analisa ini dilakukan untuk membandingkan antara asam oksalat hasil sintesis dari alang-alang dengan asam oksalat standar. Spektrum infra merah asam oksalat standard an asam oksalat hasil sintesis dapat dilihat pada Gambar 2 dan 3.

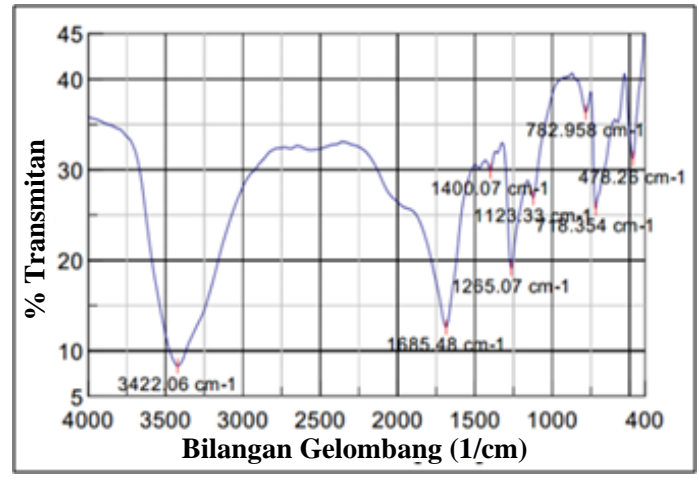

Gambar 2. Spektrum Infra Merah Asam Oksalat Standar

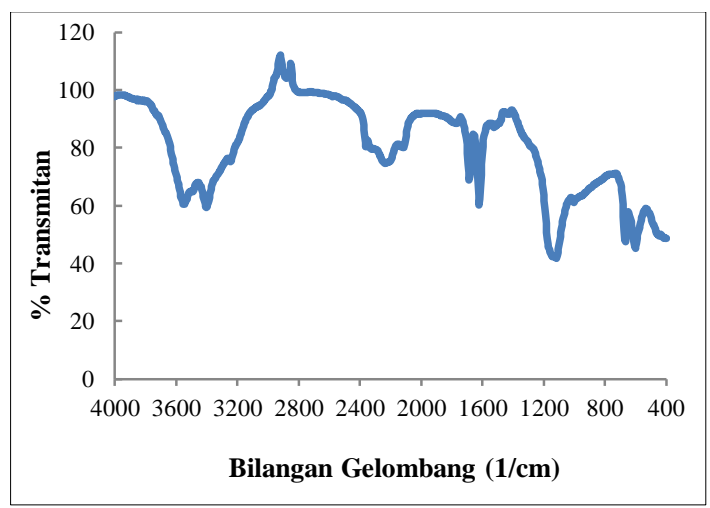

Gambar 3. Spektrum Infra Merah Asam Oksalat Hasil Sintesis dari Pelepah Kelapa Sawit

Dari Gambar 2 menunjukkan vibrasi regangan gugus hidroksil $(\mathrm{O}-\mathrm{H})$ asam oksalat standar terdapat pada bilangan gelombang 3200 - 3700 $\mathrm{cm}^{-1}$. Gugus hidroksil dikarakterisasi pada serapan kuat dan tajam pada 3422,06 $\mathrm{cm}^{-1}$. Sementara gambar 3 menunjukkan bahwa asam oksalat hasil sintesis dari pelepah kelapa sawit memiliki vibrasi regangan gugus hidroksil pada bilangan gelombang $3402,43 \mathrm{~cm}^{-1}$. Vibrasi regangan gugus $\mathrm{C}=\mathrm{C}$ asam oksalat standar terdapat pada bilangan gelombang 1685,48, sedangkan untuk asam oksalat sintesis terdapat pada bilangan gelombang 1685,79/1620,21.
Vibrasi regangan gugus C-O asam oksalat standar terdapat pada bilangan gelombang 1123,33, sedangkan untuk asam oksalat sintesis terdapat pada bilangan gelombang 1118,71. Vibrasi regangan gugus $\mathrm{C}-\mathrm{H}$ asam oksalat standar terdapat pada bilangan gelombang 718,35, sedangkan untuk asam oksalat sintesis terdapat pada bilangan gelombang 667,37.

Dari vibrasi rentangan antara asam oksalat standar dengan asam oksalat hasil sintesis pelepah kelapa sawit memiliki puncak yang tidak jauh berbeda. Hal ini membuktikan bahwa dalam penelitian ini, senyawa yang dihasilkan merupakan asam oksalat.

Analisa Titik leleh

Berdasarkan analisis di laboratorium, kristal asam oksalat yang dihasilkan memiliki titk leleh sebesar $101,5{ }^{\circ} \mathrm{C}$. Asam oksalat murni memiliki titik leleh sebesar $101,5^{\circ} \mathrm{C}$ [5].

\section{Kesimpulan}

Pelepah kelapa sawit mengandung kadar selulosa sebesar $31 \%$ sehingga dapat dimanfaatkan sebagai bahan baku dalam pembuatan asam oksalat. Pada reaksi oksidasi tersebut, temperatur dan waktu reaksi memiliki pengaruh terhadap yield asam oksalat yang diperoleh. Yield akan meningkat dengan naiknya temperatur dan waktu reaksi, sampai pada satu titik maksimum dan kemudian menurun. Persen yield terbesar diperoleh pada kondisi temperatur reaksi $80{ }^{\circ} \mathrm{C}$ dan waktu reaksi 50 menit yaitu sebesar $23,2 \%$ dan untuk operasional disarankan menggunakan temperatur $75 \%$. Hasil analisis fisik yang dilakukan terhadap kristal asam oksalat menyatakan bahwa sifat kristal asam oksalat yang dihasilkan telah sesuai dengan sifat kristal asam oksalat standar.

\section{Daftar Pustaka}

[1] Darni Subari, "Utilization of Oil Palm Midrib Waste for Particleboard with an Adhesive Mixture of Phenol Formaldehyde and Acacia Tannin", IOSR Journal of Environmental Science, Toxicology and Food Technology (IOSR-JESTFT), Volume 8 (Januari 2014), hal : $10-15$.

[2] Eldo Sularto Marbun. "Sintesis Bioplastik dari Pati Ubi Jalar Menggunakan Penguat Logam ZnO dan Penguat Alami Selulosa”. Skripsi, Program Sarjana Fakultas Teknik Universitas Indonesia, Depok, 2012.

[3] Jenny Elisabeth dan Simon P. Ginting, Pemanfaatan Hasil Samping Industri Kelapa Sawit Sebagai Bahan Pakan Ternak Sapi Potong (Medan : Pusat Penelitian Kelapa Sawit, 2003). 
[4] Jyoti D Mane, et al., "Utilisation of Sugarcane Trash and Other Cellulosic Wastes for Production of Oxalic Acid", Biological Waste 25 (1988), hal : 171-176.

[5] Kirk Othmer, Encyclopedia of Chemical Technology, Volume 1. Fourth Edition (2007).

[6] Kuponiyi, Theresa I Edewor dan Omotayo S Amuda. "Evaluation of the Production of Oxalic Acid from Some Solid Industrial Wastes in Nigeria". International Journal of Basic and Applied Science. Vol. 02, No. 01. July 2013. E-ISSN : 2301-4458; P-ISSN : 2301-8038, hal : 91-97.

[7] M. D Mathew, M. Gopal, S. K. Banerjee, "Preparation of Oxalic Acid from Jute Stick, an Agrowaste", Indian Council of Agricultural Research. Agricultural Wastes 11 (1984), hal : 47-59.

[8] Medonna Febrina Putri, Dita Permata Sari, Adisty Caesari, Gilda Miranda (2013). Biobleaching Pelepah Sawit Sebagai Bahan Baku Pembuatan Nitroselulosa Menggunakan Enzim Xylanase. http://artikel.dikti.go.id

[9] Ni Ketut Sari, "Vapor - Liquid Equilibrium (VLE) Water - Ethanol from Bulrush Fermentation", Jurnal Teknik Kimia, Volume 5, No. 1, (September 2010).

[10] P. I. Oghome, K. O. Amanze, C. I. O. Kamalu, A. C. Nkwocha, S. O. Opebiyi, "Comparative Analysis of Oxalic Acid Produced from Rice Husk dan Paddy", International Journal of Engineering Science and Technology (IJEST), IV (September 2012).

[11] Pamilia Coniwanti, Oktarisky, Rangga Wijaya, "Pemanfaatan Limbah Sabut Kelapa Sebagai Bahan Baku Pembuatan Asam Oksalat dengan Reaksi Oksidasi Asam Nitrat", Jurnal Teknik Kimia, 4(15) 2008.

[12] Podgorski, Waldemar dan Wladyslaw Lesniak. "Oxalic Acid Production by Aspergillus Niger". Food Biotechnology Department, Institute of Chemistry and Food Technology, Wroclaw University of Economics. 2003.

[13] Silvia Asri Padil dan Yelmida Aziz. "Penentuan Temperatur Terhadap Kemurnian Selulosa- $\alpha$ Batang Sawit Menggunakan Ekstrak Abu TKS". Skripsi, Program Sarjana Fakultas Teknik Universitas Riau, Pekanbaru, 2010.

[14] Widiatmini Sih Winanti (2014). Pengembangan dan Alih Teknologi untuk Mitigasi dan Adaptasi Perubahan Iklim, Dewan Nasional Perubahan Iklim. 